DOI: $10.2478 / \mathrm{v} 10025-008-0006-1$

JOURNAL OF WATER

AND LAND DEVELOPMENT

J. Water Land Dev. No. 11, 2007: 71-77

\title{
Impact of extreme climate years on relative "yield - evapotranspiration" relationships
}

\author{
Bojidara MLADENOVA, Ivan VARLEV
}

Research Institute for Land Reclamation and Agricultural Mechanization, 3 Shosse Bankya Str., Sofia, Bulgaria; e-mail: bmladenova@mail.bg

\begin{abstract}
The relative relationships "yield - evapotranspiration" were used long time ago. The well known linear relationship $y i=1-k y(1-e i)$, where $y i$ is relative yield, $k y-$ yield response factor and $e i$ - relative evapotranspiration was proposed. It's usually assumed that $k y$ is constant for a given crop and climatic conditions. It was found, however, that $k y$ for late variety of maize $\mathrm{H} 708$ varied through the study years (1984-1990) in the Plovdiv region (South Bulgaria, altitude $150 \mathrm{~m}$ ). During the dry years it was significantly higher than in the medium and humid years. The range of $k y$ for maize in this location was $1.12-1.90$, the average value being 1.50 . The climate in the Sofia region (the experimental field of Chelopechene, altitude $550 \mathrm{~m}$ ) is comparatively more humid. The two regions approximately outlined the boundaries of the appropriate economical conditions for grain maize production. The experiments in the Sofia region were carried out in the years 1994-2000. The seven years results for mean variety maize showed that the relationships "yield - evapotranspiration" and, respectively, $k y$ varied at these climatic conditions too. The highest $k y$ value was 1.41 for the driest year (2000) and the lowest value - 1.05 for the most wet years $(1995,1999)$. The value of $k y$ for average years was 1.21. The yield response factor $k y$ is of more significance when the relative evapotranspiration is less than $0.7-0.8$. Thus, the extreme or the average values of $k y$ could be used for the corresponding climatic regions. The relationships between $k y$ and relative yield were established without considering irrigation.
\end{abstract}

Key words: climate, evapotranspiration, maize, yield, yield response factor

\section{INTRODUCTION}

In Bulgaria, as in other parts of the world, specific climate changes have been observed during the past 50 years. These changes are not of catastrophic nature but have significant impact on agriculture.

The relative relationships "yield - evapotranspiration" represent the essential influence of the amounts of used water on obtained yields. Owing to this fact they are extensively used in the design and operation of the irrigation systems. It is as- 
sumed that these relationships are constant for a given geographic region and for specific crops and hybrids.

This research aims at establishing the changes of the relative relationships "yield - evapotranspiration" for maize in Bulgaria during the years of extreme and average climate.

\section{MATERIAL AND METHODS}

In the years 1994-2000, experiments with maize (500, according to FAO) were carried out at the Chelopechene farm (Sofia region). The altitude of the field is $550 \mathrm{~m}$ a.s.l. and the sum of the effective temperatures during the vegetation season is $3009^{\circ} \mathrm{C}$. The soil type is leached cinnamon forest. The average values for the $1 \mathrm{~m}$ deep soil layer are: field capacity $-21.8 \%$, wilting point $-11.3 \%$ and absolute dry matter weight $-1.5 \mathrm{~g} \cdot \mathrm{cm}^{-3}$. The water regime in different variants of experiments was realized with a wide range of irrigation depths - from 0.0 to $1.3 \mathrm{~m}$ of the net irrigation requirement.

The humidity in the specific year is characterized by two indices. The first is the precipitation sum in $\mathrm{mm}$ during the irrigation period, which for the region of Sofia comprises July and August. The second index is the relative yield without irrigation $(y o)$. It represents the ratio between the yield without irrigation $(Y o)$ and the maximum yield $(\mathrm{Ym})$ obtained at full satisfaction of the plant water demands. Given the continental climate of Bulgaria, the values of the index yo fall within the range $0.2-0.7$ (in extreme years $0.0-1.0$ ). This wide range makes the integral index yo especially suitable for drought intensity assessment.

For many years, the relationship between yield decrease and evapotranspiration deficiency (DOORENBOS, 1979) has been widely used.

$$
(1-Y a / Y m)=k y(1-E T a / E T m)
$$

where

$\mathrm{Ya} \quad$ - actual harvested yield, $\mathrm{kg} \cdot \mathrm{ha}^{-1}$;

ky - yield response factor;

ETa - actual evapotranspiration, $\mathrm{mm}$;

ETm - maximum evapotranspiration, $\mathrm{mm}$.

After simple transformation, equation 1 can be expressed in relative terms as a relationship between yield and evapotranspiration.

$$
y i=1-k y(1-e i)
$$

where: $y i=Y a / Y m ; e i=E T a / E T m$. 


\section{RESULTS}

The experimentally established values of the relative evapotranspiration are from 0.4 to 1.0 , while the relative yields range from 0.26 to 1.00 . If the data are divided into three groups, the results presented in Figures 1, 2 and 3 will be obtained.

Figure 1 shows the results for the relationship between relative yield and relative evapotranspiration obtained in the course of 4 average climate years at the Chelopechene experimental farm. It can be seen that the relative evapotranspiration is in the range of 0.57-1.00. Yield response factor $k y$ is 1.21 . The coefficient of determination in this case is high $-R^{2}=0.926$.

The data in Figure 2 relate to wet years (1995 and 1999) which are characterized by relative yield without irrigation $-y o$ about 0.74 . The mean probability of exceeding the precipitation sum for July and August is 32\%. It can be seen that for these two years the crop response factor $k y$ is 1.05 , i.e. smaller than $k y$ for the average year (1.21).

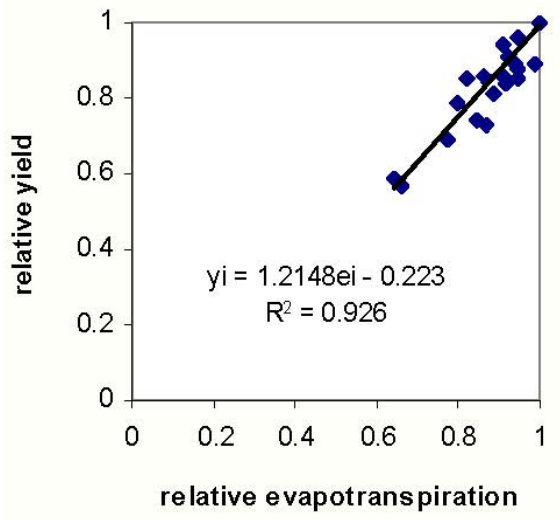

Fig. 1. Relative relationship "yield - evapotranspiration" for maize (500, FAO) obtained in average years

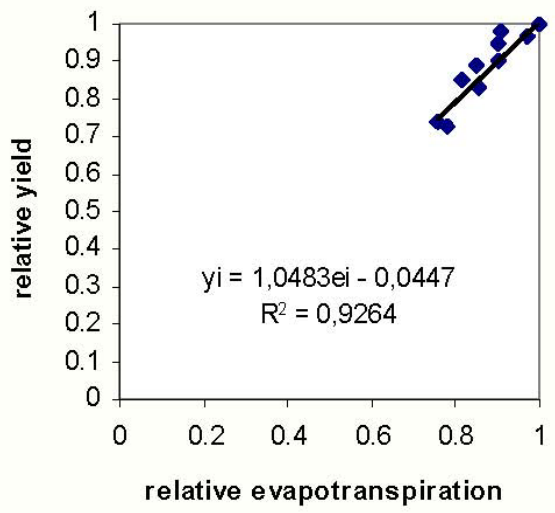

Fig. 2. Relative relationship "yield - evapotranspiration" for maize obtained in the wet 1995 and 1999 years

The results in Figure 3 pertain to the dry 2000 year. In that year the relative yield without irrigation was comparatively low $-y o=0.26$ and the probability of exceeding the precipitation sum was extremely high $-P=99 \%$. The value of the $k y$ coefficient was the highest of all results obtained $-k y=1.41$. It can be seen from Figures 2 and 3 that the coefficients of determination are $R^{2}=0.93$.

At the next step of data processing the relationships yield - evapotranspiration were determined separately for each year. The values obtained for the $k y$ coefficient are shown in Figure 4 depending on the relative yield without irrigation $-y o$. The established relationship is: 


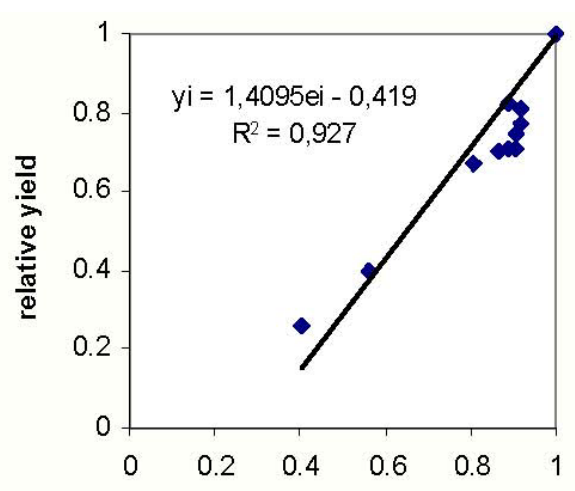

relative evapotranspiration

Fig. 3. Relative relationship "yield - evapotranspiration" for maize obtained in the dry 2000 year

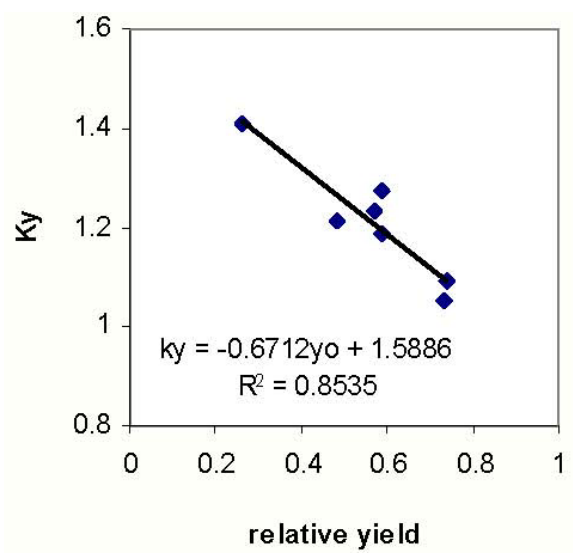

Fig.4. Relationship between $k y$ and the relative yield without irrigation $-y o$, under the conditions of the Sofia region

$$
k y=1.59-0.67 y o ; \quad R^{2}=0.85
$$

When humidity of a given year, characterized by the parameter yo, is known, one can easily determine the crop response factor $k y$ (Figure 4 and equation 3 ). This coefficient $k y$ is typical for a certain climatic region.

In the 1984-1990 period, experiments similar to the ones described above were conducted in the Plovdiv region using the H-708 hybrid (VARLEV et al., 1994). The average altitude of the region is $150 \mathrm{~m}$, the sum of effective temperatures during the vegetation season is $3472^{\circ} \mathrm{C}$, and the average rainfall is about 200 $\mathrm{mm}$. The Plovdiv region is representative for climate of the main part of the Thrace Valley in South Bulgaria. It is evident from presented data that the climate in Plovdiv region is considerably warmer than that of the Sofia region.

After processing all data from the Plovdiv region, separately for each of the seven years, it was found that the slope of the straight lines, i.e. the crop response factor $k y$, was quite different. During the driest year (1990) the relative yield without irrigation was $y o=0.0$, and the coefficient $k y$ reached its maximum -1.90 . During the wettest year (1984), when yo $=0.41, k y$ had a minimum value of 1.12 . The regression of $k y$ on yield is:

$$
k y=1.04 \exp (-4.5 y o)
$$

It should be noted that the experimentally established values of the relative evapotranspiration are from 0.30 to 1.0 , while the relative yields range from 0.0 to 1.0. Thus the whole possible range of the obtained relationships is covered.

The average coefficient $k y$ for the region of South Bulgaria, which has a definitely warmer climate, is 1.50 . It varied between 1.12 and 1.90 in the course of ex- 
treme climatic years. For the region of Sofia the value of $k y$ for the average year is 1.21. During the extreme climatic years it changed from 1.05 to 1.41 in both regions for the wettest and driest years, respectively.

The Plovdiv and Sofia regions are the "climatic limits" between which it is feasible to grow maize for grain in Bulgaria. Large grain producing regions of North Bulgaria are situated within these borders.

For the sake of practical use, the results obtained were rounded and summed up for three types of years depending on their humidity (Tab. 1).

Table 1. The value of $k y$ coefficient for different years

\begin{tabular}{l|c|c|c}
\hline \multirow{2}{*}{ Region } & \multicolumn{3}{|c}{$k y$ in the } \\
\cline { 2 - 4 } & wet year & average year & dry year \\
\hline Plovdiv - South Bulgaria & 1.30 & 1.50 & 1.75 \\
Sofia region & 1.05 & 1.21 & 1.41 \\
\hline
\end{tabular}

Results from this table can be used in a number of regions in the neighbouring Balkan countries of similar climatic conditions.

In the past 3-4 decades steady trends towards warming and drying during the vegetation season have been observed in Bulgaria (SLAVOV and RouSSEVA, 2000). More specifically, in the years 1970-2000 an increase in the average temperature sum during the vegetation period by about $200^{\circ} \mathrm{C}$ was noted. For the same period the sum of precipitation decreased by about $70 \mathrm{~mm}$ (Fig. 5).

In a hypothetical, "optimistic" prognosis to 2025 it has been assumed that precipitation and air temperature will return to the level from around 1970. In this case, the $k y$ coefficients would be within the range given in the table, as they were established in the 1984-2000 period.

In a "realistic" prognosis to 2025 it is assumed that precipitation, temperature, etc., will remain around levels found for the 2000 trend. It means that the values of $k y$ coefficients will augment above the values in the table. Therefore, according to the "realistic" prognosis the demands for irrigation water per unit area will increase. On the one side, it will depend on reduced precipitation and the temperature increase. On the other side, however, the established increase of the $k y$ coefficient during dry years means that in order to obtain a certain yield $\mathrm{Ya}$ a larger amount of water will be needed. If this "realistic" prognosis materializes, water demand for irrigation will increase by c. $20 \%$.

In a "pessimistic" prognosis it is believed that the trend for precipitation (Fig. 5) and temperature changes, determined in the 1970-2000 period, will remain till 2025. In this case, the water needs and, respectively, the yields without irrigation, will undergo even more significant changes, unfavourable for the countries' economies. 


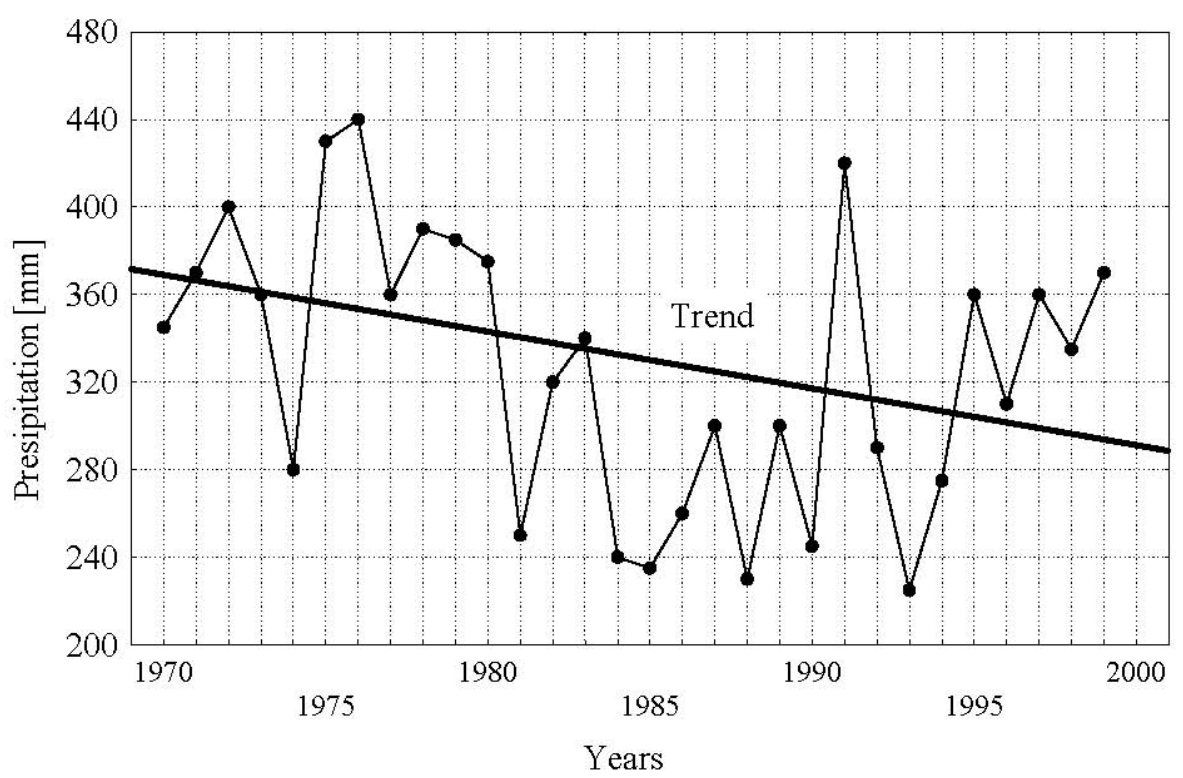

Fig. 5. Changes and trend of the sum of precipitation during the 1970-2000 period (SLAVOV and RousSEVA, 2000)

\section{CONCLUSIONS}

1. Seven year field experiment was conducted with the late and medium late maize varieties in the Sofia region and in South Bulgaria. It has been found that the $k y$ coefficients expressing the relative relationships between yield and evapotranspiration vary among particular climatic years. Their maximum and minimum values were obtained for extremely dry and extremely wet years, respectively.

2. Relationships were found between the coefficient $k y$ and humidity of the respective year, characterized by the relative yield without irrigation $-y o$ (eq. 3 and 4).

3. For the warmer region of the Thrace Valley (altitude $150 \mathrm{~m}$ ) mean value of the $k y$ coefficient for maize is 1.50, while for the colder Sofia region (altitude 550 m) $k y$ is 1.21 .

4. For the territory of Bulgaria, in the years 1970-2000, a stable trend has been found of increasing temperatures and decreasing precipitation. With the "realistic" prognosis till 2025, when climatic indices are at a level of that established from trend for the year 2000, the need for irrigation water per unit area will increase by about $20 \%$. 


\section{REFERENCES}

1. Slavov N., Rousseva M., 2000. Agroclimatic assesment of vegatation precepitation during the last centure. Agricultural plus, Sofia: 5-7 (in bulgarian).

2. Doorenbos J., 1979. Yield and response to water. FAO. Irrig. Drain. Paper, 33, Rome.

3. VARleV I., Kolev N., KirKova I., 1994. "Yield - water" relationships and their changes during individual climatic years. 17-th Eur. Reg. Conf. ICID, Varna, R 1. 46.

\section{STRESZCZENIE}

\section{Wpływ ekstremalnych warunków klimatycznych na względną zależność „plon - ewapotranspiracja"}

Słowa kluczowe: ewapotranspiracja, klimat, kukurydza, plon, wspótczynnik reakcji roślin na niedobory wody

W pracy przedstawiono wyniki badań nad plonami i ewapotranspiracją dwóch mieszańców kukurydzy. Badania te prowadzono w różnych okresach siedmioletnich w dwóch odmiennych klimatycznie regionach Bułgarii. Analizowane regiony wyznaczają granice obszarów opłacalnej uprawy kukurydzy na ziarno w tych warunkach klimatycznych. Przedstawiono analizę wartości wskaźnika $k y \mathrm{w}$ latach suchych, średnich i mokrych. Wykazano wyraźne zależności korelacyjne między plonami a ewapotranspiracją, potwierdzone bardzo wysokimi wartościami współczynników determinacji $R^{2}$. Wartości ewapotranspiracji aktualnej ETa i potencjalnej ETm wyznaczono na podstawie zaleceń FAO.

Badania udowodniły, że wartość ewapotranspiracji może ulec istotnej zmianie w wyniku ewentualnej zmiany klimatu. Już obecnie obserwuje się w Bułgarii wzrost temperatury i zmniejszenie opadów atmosferycznych, co może mieć duży wpływ na plonowanie roślin uprawnych.

Reviewers:

Prof. Leszek Łabędzki

Prof. Marian Rojek 